\title{
Evaluation of anti-thyroglobulin antibodies and thyroid stimulating hormone level in cases of recurrent early pregnancy loss
}

\author{
Mohamed Elmahdy $^{1 *}$, Eman T. Elsayed $^{2}$ \\ ${ }^{1}$ Department of Obstetrics and Gynaecology, ${ }^{2}$ Department of Clinical and Chemical Pathology, Faculty of Medicine, \\ Alexandria University, Egypt
}

Received: 14 August 2016

Accepted: 12 September 2016

\section{*Correspondence:}

Dr. Mohamed Elmahdy,

E-mail: mahdy_moh@yahoo.com

Copyright: ( ) the author(s), publisher and licensee Medip Academy. This is an open-access article distributed under the terms of the Creative Commons Attribution Non-Commercial License, which permits unrestricted non-commercial use, distribution, and reproduction in any medium, provided the original work is properly cited.

\section{ABSTRACT}

Background: Autoimmune thyroid disease (AITD) is by far the most frequent cause of hypothyroidism in women in reproductive age. The prevalence of hypothyroidism in the general population of reproductive age is $2-3 \%$. The objective of this study was to evaluate maternal anti-thyroglobulin (ATG) concentrations and thyroid stimulating hormone (TSH) level in cases of recurrent miscarriage.

Methods: 200 female patients divided into two groups. Group A: 100 female patients with history of recurrent miscarriage. Group B: 100 female patients with at least 2 living children and without history of recurrent early miscarriage. Antithyroglobulin antibodies using chemilumeniscence immunoassay (normal level up to $115 \mathrm{IU} / \mathrm{ml}$ ) and TSH level using chemilumeniscence immunoassay (normal level 0.350-2 U/ml) were assessed.

Results: $8.0 \%$ of cases $(n=100)$ and $2.0 \%$ of control group $(n=100)$ were positive for anti TG antibodies. There was no significant relationship between the presence of anti TG antibodies and RPL $(\mathrm{p}=0.052) .19 \%$ of cases $(\mathrm{n}=100)$ were positive for TSH level. On the other hand, $14 \%$ of control group $(n=100)$ were positive for TSH level there was no significant relation between recurrent pregnancy loss and TSH, $(\mathrm{P}=0.34)$.

Conclusions: Neither TSH nor ATG showed significant difference in cases with recurrent miscarriage.

Keywords: AITD, ATG, TSH

\section{INTRODUCTION}

Miscarriage is the spontaneous loss of the concept us before 20 weeks of gestation. Potential risk of possible miscarriage before pregnancy is diagnosed is about $30 \%$. In clinically detected pregnancy, it is $10-15 \%$ before 8 th week and $3 \%$ between $8^{\text {th }}$ and $20^{\text {th }}$ weeks. Recurrent miscarriage is defined as occurrence of two or more consecutive spontaneous miscarriage. It occurs in 1-2\% of couples in the reproductive age group. ${ }^{1-4}$

Recurrent miscarriage can be attributed to chromosomal anomalies, anticardiolipin antibodies, and endocrine disorders such as poorly controlled diabetes mellitus, hyperprolactinaemia, thyroid diseases; and pelvic anatomic abnormalities. Recurrent miscarriage can be classified as either primary or secondary. Primary cases are women who have lost all their pregnancies, whereas secondary miscarriage cases have had at least one live born infant. ${ }^{5}$

Autoimmune thyroid disease (AITD) is one of the common causes of hypothyroidism in women in the reproductive age. The prevalence of hypothyroidism in the general population of reproductive age is 2-3\%. Overt hypothyroidism is commonly associated with infertility, as thyroid hormones have a direct effect on granulose cells, theca cells and oocyte maturation. ${ }^{6-8}$

Autoimmune thyroid disorders are characterized by the presence of thyroid auto-antibodies (Abs), particularly thyroid peroxidase (TPO) auto Abs and antithymoglobulin ( $\mathrm{Tg}$ ) auto Abs. TPO is an enzyme responsible for iodination of tyrosine residues and 
coupling of iodinated residues to form thyroid hormones. ${ }^{9}$ The presence of thyroid autoantibodies is relatively common in women in reproductive age. In an "unselected" population of women, the prevalence ranges from $6 \%$ to $20 \%$, being even higher in women with a history of recurrent pregnancy loss, (17-33\%), and in women with a history of subfertility, (10-31\%) in the developed world, thyroid autoimmunity is the main cause of hypothyroidism, which itself results in poor obstetric outcomes. $^{10,11}$

Euthyroid women with thyroid autoimmunity are twice as likely to experience spontaneous miscarriages. This may be attributed to a generalised activation of the immune system, an increased risk of progression to subclinical hypothyroidism, or it could be due to the trans-placental transfer of thyroid receptor blocking antibodies. $9,12-15$

Hence, there is a need to screen for subclinical hypothyroidism and thyroid autoimmunity in pregnancy, especially in women with a history of spontaneous miscarriages. However, the management of women with recurrent miscarriage who have thyroid autoimmunity remains controversial.

The objective of this study was to evaluate the relation of maternal serum TSH and the percentage of recurrent miscarriage in cases with positive serum anti thyroid antibodies.

\section{Patients}

The study was being conducted on 200 women in the age group of 21-35 years recruited from the outpatient antenatal care clinic in El Shatby Maternity university Hospital. The study was conducted from September 2014 till October 2015.

This study has been approved by national research ethics committee and has been performed in accordance with the ethical standards as laid down in the 1964 Declaration of Helsinki and its later amendments or comparable ethical standards.

Informed consent was obtained from all individual participants included in the study.

\section{Patients were divided in two groups}

- Group A: 100 female patients with history of recurrent miscarriage

- Group B: 100 female patients with at least 2 living children and without history of miscarriage.

\section{Inclusion criteria}

- $\quad$ Patients within the reproductive age (21-35)

- Women with recurrent first trimester pregnancy loss (two or more first trimester pregnancy loss) ${ }^{1}$
- The control group: women with at least 2 living children and without history of miscarriage.

\section{Exclusion criteria}

- Women with known autoimmune disorders including patients with systemic lupus, antiphospholipid syndrome and anticardiolipin antibody sero positive patients

- Women with history of cervical incompetence or any other uterine pathology

- Women already on treatment for thyroid dysfunction

- Women with known chromosomal disorders

- Women with known medical disorders as hypertension and diabetes.

\section{METHODS}

All the patients were subjected to

\section{Written informed consent}

\section{Detailed history taking}

- Personal history: age, smoking, alcohol and drug intake. Medical as hypertension and diabetes. Surgical as thyroid operation. Obstetric history: gravidity, parity and Past history of abortion including number of abortions and duration of pregnancy in each.

\section{Complete general examination including}

- General look as pallor, jaundice and tremors

- Vital signs blood pressure pulse, temperature and respiratory rate

- Head and neck examination to exclude thyroid swelling

- Chest and cardiac examination

- Abdominal examination to exclude abdominal and pelvic tumor.

Ultrasound scanning to exclude any pelvic pathology.

Karyotyping to exclude chrmosomal anaomalies.

Laboratory investigations including:

- Routin investigations:-complete blood picture, blood group, $\mathrm{RH}$ and fasting blood glucose level

\section{Special investigation}

- Antithyroglobulin antibodies (antithyroglobulin auto antibodies) using chemiluminescence immunoassay. (Normal level up to $115 \mathrm{IU} / \mathrm{ml}$.)

- TSH level using chemiluminescence immunoassay. (Normal level 0.350-5.500Uu/ml). 


\section{RESULTS}

The study was conducted on 200 women in the reproductive age and was divided into two groups; group A: 100 female patients with history of recurrent miscarriage and group B: 100 female patients with at least 2 living children and without history of miscarriage.

There was no statistically significant difference between the two groups regarding age. The mean was $27.56 \pm 5.24$ in the first group and $26.97 \pm 4.23$ in the second group ( $\mathrm{p}=$ 0.382).
There was no statistically significant difference between the two studied groups regarding TSH level $(2.95 \pm 3.19$

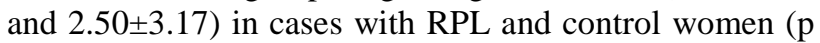
$=0.34)$ (Table 1$)$.

In group A (cases group) the level of antithyroglobulin auto antibodies was normal in 92 patients and abnormal in 8 patients with a mean value of $65.81 \pm 139.0$. In group B (control group) the level of antithyroglobulin auto antibodies was normal in 98 patients and abnormal in 2 patients with a mean value of $42.70 \pm 140.93$. There is no statistically significant difference between the two groups regarding antithyroglobulin auto antibodies level $(\mathrm{p}=$ 0.052) (Table 2).

Table 1: Comparison between the two studied cases according to TSH.

\begin{tabular}{|c|c|c|c|c|c|c|}
\hline & \multicolumn{2}{|c|}{ Cases $(n=100)$} & \multicolumn{2}{|c|}{ Control $(n=100)$} & \multirow{2}{*}{ Test of sig. } & \multirow{2}{*}{$\mathbf{P}$} \\
\hline & No. & $\%$ & No. & $\%$ & & \\
\hline \multicolumn{7}{|l|}{ TSH } \\
\hline Normal $(\leq 3)$ & 81 & 81 & 86 & 86 & \multirow{2}{*}{$\chi^{2}=1.332$} & \multirow{2}{*}{${ }^{\mathrm{FE}} \mathrm{p}=0.34$} \\
\hline Abnormal $(>3)$ & 19 & 19 & 14 & 14 & & \\
\hline Min.-Max. & \multicolumn{2}{|c|}{$0.36-23.60$} & \multicolumn{2}{|c|}{$0.43-23.80$} & \multirow{3}{*}{$Z=1.955$} & \multirow{3}{*}{0.051} \\
\hline Mean \pm SD. & \multicolumn{2}{|c|}{$2.95 \pm 3.19$} & \multicolumn{2}{|c|}{$2.50 \pm 3.17$} & & \\
\hline Median & \multicolumn{2}{|c|}{2.40} & \multicolumn{2}{|c|}{2.04} & & \\
\hline
\end{tabular}

$\chi^{2}$ : Chi square test; FE: Fisher Exact test; Z: Z for Mann Whitney test

Table 2: Comparison between the two studied cases according to antithyroglobulin.

\begin{tabular}{|c|c|c|c|c|c|c|}
\hline & \multicolumn{2}{|c|}{ Cases $(n=100)$} & \multicolumn{2}{|c|}{ Control $(n=100)$} & \multirow{2}{*}{ Test of sig. } & \multirow{2}{*}{$\mathbf{P}$} \\
\hline & No. & $\%$ & No. & $\%$ & & \\
\hline \multicolumn{7}{|l|}{ Antithyroglobulin } \\
\hline Normal $(\leq 115)$ & 92 & 92.0 & 98 & 98.0 & \multirow{2}{*}{$\chi^{2}=3.789$} & \multirow{2}{*}{0.052} \\
\hline Abnormal (>115) & 8 & 8.0 & 2 & 2.0 & & \\
\hline Min.-Max. & \multicolumn{2}{|c|}{$12.87-672.50$} & \multicolumn{2}{|c|}{$26.60-415.50$} & \multirow{3}{*}{$Z=7.504^{*}$} & \multirow{3}{*}{$<0.001^{*}$} \\
\hline Mean \pm SD. & \multicolumn{2}{|c|}{$65.81 \pm 139.0$} & \multicolumn{2}{|c|}{$42.70 \pm 40.93$} & & \\
\hline Median & \multicolumn{2}{|c|}{26.0} & \multicolumn{2}{|c|}{35.50} & & \\
\hline
\end{tabular}

$\chi^{2}$ : Chi square test; Z: Z for Mann Whitney test*; Statistically significant at $\mathrm{p} \leq 0.05$

Table 3: Relation between no. of abortion with TSH.

\begin{tabular}{|c|c|c|c|c|}
\hline & \multicolumn{2}{|c|}{ No. of abortion } & \multirow{2}{*}{$\mathbf{Z}$} & \multirow{2}{*}{$\mathbf{P}$} \\
\hline & $\leq 3(n=50)$ & $>3(n=50)$ & & \\
\hline \multicolumn{5}{|l|}{ TSH } \\
\hline Min.-Max. & $0.4-20.65$ & $0.36-23.60$ & \multirow{3}{*}{$\begin{array}{l}0.35 \\
5\end{array}$} & \multirow{3}{*}{0.722} \\
\hline Mean \pm SD. & $2.88 \pm 2.95$ & $3.02 \pm 3.44$ & & \\
\hline Median & 2.48 & 2.40 & & \\
\hline
\end{tabular}

When cases with more than three abortions compared with cases with three or less abortions. There was no statistical significant difference as regards serum level of TSH $(2.88 \pm 2.95$ and 3.02 \pm 3.44$)$ in cases with more and less than three miscarriage $(\mathrm{p}=0.722)$ (Table 3$)$. There were no statistical significant difference between both groups as regards serum antithyroglobulin $\mathrm{AB}$ $(55.05 \pm 121.39$ and $76.56 \pm 155.12)$ in cases with more and less than three miscarriage $(\mathrm{p}=0.357)$ (Table 4$)$.

Table 4: Relation between no. of abortion with antithyroglobulin.

\begin{tabular}{|c|c|c|c|c|}
\hline \multicolumn{3}{|c|}{ No. of abortion } & \multirow{2}{*}{$\mathbf{Z}$} & \multirow{2}{*}{$\mathbf{P}$} \\
\hline & $\leq 3(n=50)$ & $>3(n=50)$ & & \\
\hline \multicolumn{5}{|c|}{ Antithyroglobulin } \\
\hline Min.-Max. & $13.80-672.50$ & $12.87-666.10$ & \multirow{3}{*}{0.920} & \multirow{3}{*}{0.357} \\
\hline Mean \pm SD. & $55.05 \pm 121.39$ & $76.56 \pm 155.12$ & & \\
\hline Median & 26.05 & 24.80 & & \\
\hline
\end{tabular}

$\mathrm{Z}$ : Z for Mann Whitney test 


\section{DISCUSSION}

The aim of this study was to evaluate maternal antithyroglobulin $(\mathrm{Tg})$ auto Abs concentrations and $\mathrm{TSH}$ level in cases of recurrent miscarriage as there is a debate between this correlation.

In the present study there was no significant difference between serum level of TSH in the two studied groups

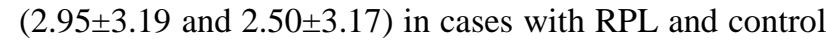
women $(p=0.34)$ respectively. Serum anti thyroglobulin level showed a non-significant elevation in the group with recurrent pregnancy loss than in the control group ( $\mathrm{p}$ $=0.052$ ).

These results were in agreement with Pratt and his colleagues who failed to reach statistical significance $(\mathrm{p}=$ 0.2 ) when they were tried to evaluate women with recurrent abortions for the presence of thyroid Abs compared with the controls. ${ }^{16}$ Also, Esplin and his colleagues compared the rate of thyroid auto antibodies positivity in women with recurrent abortion with controls (p>0.05 not statistically significant). ${ }^{17}$ In a study conducted in the same year, no difference was found in miscarriage rates between Ab-negative and Ab-positive women $(\mathrm{p}=0.29) .{ }^{18}$ In addition, it was concluded that the risk of pregnancy loss in women with unexplained recurrent miscarriages is not affected by their thyroid Abs status. ${ }^{19}$

On the other hand, the present results were not concordant with some other studies in this field. Other researchers who found a relationship between thyroid autoantibodies and abortion. Stagnaro-Green and his colleague Glinoer were reported a doubling of the miscarriage rate in women who were positive with antithyroid Abs compared to those with negative Abs ( $p$ $=0.011, \mathrm{p}<0.001)$, respectively. ${ }^{20,21}$ Also, Lejeune and his colleague were reported that the miscarriages are associated with antithyroid Abs and took place early, within the first trimester of the pregnancy. ${ }^{22}$ Several researchers reported that women with TPO Abs and/or TG Abs had a higher miscarriage rate than women who were negative for these $\mathrm{Abs}(\mathrm{P}<0.05)$ respectively. ${ }^{23-26}$

In the present study, thyroid dysfunction in the form of abnormal serum TSH level and serum antithyroglobulin $\mathrm{AB}$ showed no correlation with the number of pregnancy loss if we compared women with more and less than 3 miscarriages. This may be supported also by what was found that thyroglobulin message is not expressed in placenta, decidua, or ovary in any stages of pregnancy. The same results were obtained at the protein level. ${ }^{27}$

In the present study, we only studied on type of antithyroid antibodies (ATG), while there is other antibodies such as anti thyoid peroxidase AB (anti TPO) which were not tested in this study and may have a role in recurrent pregnancy loss. Antithyroid antibodies are known to occur in normal, healthy population, and these auto antibodies are five times more common in women than in men. Because of prominent prevalence of antithyroid antibodies in normal women, interpreting the significance of these antibodies in women with reproductive problems remains difficult. ${ }^{22}$ It is also suggested that the presence of thyroid auto antibodies reflects a generalized activation of the immune system particularly of $\mathrm{T}$ cells, which are ultimately responsible for the loss of the pregnancy. ${ }^{23}$ So, the effect of these Abs seen by some studies may reflect only some sort of association due to immunological over activity.

\section{CONCLUSION}

Thyroid dysfunction in the form of abnormal serum TSH level and serum antithyroglobulin $\mathrm{AB}$ levels had no correlation with recurrent early miscarriage or to the numbers of miscarriages.

\section{ACKNOWLEDGEMENTS}

Authors would like to thanks to the clinical pathology team due to their assistance.

Funding: No funding sources

Conflict of interest: None declared

Ethical approval: The study was approved by the Institutional Ethics Committee

\section{REFERENCES}

1. Practice Committee of the American Society for Reproductive Medicine. Definitions of infertility and recurrent pregnancy loss. Ferti Ster. 2008;90:S60.

2. Brigham SA, Conlon C, Farquharson RG. A longitudinal study of pregnancy outcome following idiopathic recurrent miscarriage. Human Reproduction. 2009; 14:2868-71.

3. Tulppala M, Palosuo T, Ramsay T, Miettinen A, Salonen R, Ylikorkala OA. A prospective study of 63 couples with a history of recurrent spontaneous abortion: contributing factors and outcome of subsequent pregnancies. Human Reproduction. 2000;8:764-70.

4. Carrington B, Sacks G, Regan L. Recurrent miscarriage: pathophysiology and outcome. Cur Opi Obste Gynec. 2010;17:591-7.

5. Li TC, Makris M, Tomsu M, Tuckerman E, Laird S. Recurrent miscarriage: etiology, management and prognosis. Hum Repro Updates. 2012;8:463-81.

6. Poppe K, Glinoer D. Thyroid autoimmunity and hypothyroidism before and during pregnancy. Hume Rep. 2003;9:149-61.

7. Klein RZ, Haddow JE, Faix ZE. Prevalence of thyroid deficiency in pregnancy. Clin Endo. 1999;35:41-6.

8. Wakim AN, Polizotto SL, Buffo MJ, Marrero MA, Burholt DR. Thyroid hormones in human follicular fluid and thyroid hormone receptors in human granulosa cells. Ferti Ster. 1999;59:1187-90. 
9. Twig G, Shina A, Amital H, Shoenfeld Y. Pathogenesis of infertility and recurrent pregnancy loss in thyroid autoimmunity. J Auto. 2012;38:27581 .

10. Kennedy RL, Malabu UH, Jarrod G, Nigam P, Kannan K, Rane A. Thyroid function and pregnancy: Before, during and beyond. J Obstet Gynaecol. 2010;30:774-83.

11. Glinoer D, Soto MF, Bourdoux P, Lejeune B, Delange F, Lemone M, et al. Pregnancy in patients with mild thyroid abnormalities: maternal and neonatal repercussions. Clin Endocrinol Metab. 1999;73:421-7.

12. Faussett MB, Branch DW. Autoimmunity and pregnancy loss. Semi Reprod Med. 2010;18:379-92.

13. Pratt DE, Kaberlein G, Dudkiewicz A, Karande V, Gleicher N. The association of antithyroid antibodies in euthyroid non-pregnant women with recurrent first trimester abortions in the next pregnancy. Fertil Steri. 1999;60:1001-5.

14. Glinoer D, Delange F. The potential repercussions of maternal, fetal, and neonatal hypothyroxinemia on the progeny. Thyroid. 2000;10:871-87.

15. Kutteh WH, Yetman DL, Carr AC, Beck LA, Scott RT. Increased prevalence of antithyroid antibodies identified in women with recurrent pregnancy loss but not in women undergoing assisted reproduction. Fertil Steril. 1999;71(5):843-8.

16. Esplin MS, Branch DW, Silver R, Stagnaro-Green A. Thyroid autoantibodies are not associated with recurrent pregnancy loss. Am J Obstet Gynecol. 1998;179(6 Pt 1):1583-6.

17. Pratt E, Kaberlein G, Dudkiewicz A, Karande V, Gleicher N. The association of antithyroid antibodies in euthyroid non-pregnant women with recurrent first trimester abortions in the next pregnancy. Fertil Steril. 1993;60:1001-5.

18. Muller AF, Verhoeff A, Mantel MJ, Berghout A. Thyroid autoimmunity and abortion: a prospective study in women undergoing in vitro fertilization. Fertil Steril. 1999;71(1):30-4.
19. Rushworth FH, Backos M, Rai R, Chilcott IT, Baxter $\mathrm{N}$, Regan L. Prospective pregnancy outcome in untreated recurrent miscarriers with thyroid autoantibodies. Hum Reprod. 2000;15(7):1637-9.

20. Stagnaro-Green A, Glinoer D. Thyroid autoimmunity and the risk of miscarriage. Best Pract Res Clin Endocrinol Metab. 2004;18(2):167-81.

21. Glinoer D. Thyroid hyperfunction during pregnancy. Thyroid. 1998;8:859.

22. Lejeune B, GruEn JP, De Nayer P, Servais G, Glinoer D. Antithyroid antibodies underlying thyroid abnormalities and miscarriage or pregnancy induced hypertension. Br J Obstet Gynaecol. 1993;100:66972.

23. Bussen SS, Steck T. Thyroid antibodies and their relation to antithrombin antibodies, anticardiolipin antibodies and lupus anticoagulant in women with recurrent spontaneous abortions antithyroid, anticardiolipin and antithrombin autoantibodies and lupus anticoagulant in habitual aborters. Eur J Obstet Gynecol Reprod Biol. 1997;74:139-43.

24. Iijima T, Tada H, Hidaka Y, Mitsuda N. Effects of autoantibodies on the course of pregnancy and fetal growth. Obstet Gynaecol. 1997;90:364-9.

25. Dendrinos S, Papasteriades C, Tarassi K, Christodoulakos G. Thyroid autoimmunity in patients with recurrent spontaneous miscarriages. Gynecol Endocrinol. 2000;14:270-4.

26. Negro R, Formoso G, Mangieri T, Pezzarossa A, Dazzi D, Hassan H. Levothyroxine treatment in euthyroid pregnant women with autoimmune thyroid disease: effects on obstetrical complications. J Clin Endo Metab. 2006;91(7):2587-91.

27. Moravej A, Jeddi-Tehrani M, Salek-Moghaddam AR, Dokouhaki P, Ghods R, Rabbani H, et al. Evaluation of thyroglobulin expression in murine reproductive organs during pregnancy. Am J Reprod Immunol. 2010;64(2):97-103.

Cite this article as: Elmahdy M, Elsayed ET. Evaluation of anti-thyroglobulin antibodies and thyroid stimulating hormone level in cases of recurrent early pregnancy loss. Int J Reprod Contracept Obstet Gynecol 2016;5:3312-6. 